\title{
Research of Kinetics of Coal Briquette Drying and Determination of the Optimum Mode Providing Fire and Explosion Safety
}

\author{
Vasily Murko ${ }^{1, *}$, Anatoly Zaostrovsky², Elena Murko ${ }^{3}$, and Mikhail Volkov ${ }^{4}$ \\ ${ }^{1}$ T.F. Gorbachev Kuzbass State Technical University, Department of Theoretical and Geotechnical \\ Mechanics, 650000 Kemerovo, 28 Vesennya st., Russian Federation \\ ${ }^{2}$ Federal Research Center for Coal and Coal Chemistry, Siberian Branch of the Russian Academy of \\ Sciences, 650000 Kemerovo, 18 Soviet pr., Russian Federation \\ ${ }^{3}$ T.F. Gorbachev Kuzbass State Technical University, Department of Postgraduate Studies, Doctorate, \\ 650000 Kemerovo, 28 Vesennya st., Russian Federation \\ ${ }^{4}$ JSC SUEK-Kuzbass, Office of long-term development and licensing, 652507 Leninsk-Kuznetskiy, 1 \\ Vasilyeva st, Russian Federation
}

\begin{abstract}
The role coal in power industry is predicted to be increased in future that is caused by its large stocks and depletion of oil and gas fields. Due to production growth, deterioration in mining and geological conditions and broad mechanization of production, the quality characteristics of coals as ash content, particle-size distribution, humidity and sulfur content worsen. Therefore, practically all mined coal requires enriching. The smallgrade and fine concentrates received after enrichment often happen to be unsuitable because of their fineness for further processing or direct use. Therefore briquetting is applied for possibility of further processing or increased utilization efficiency. Compared to the conventional fuel the briquetted fuel possesses higher calorific capacity and bigger stability during storage and transportation.
\end{abstract}

\section{Introduction}

By now several briquetting plants have appeared in Kuzbass (Siberian Briquette in Novokuznetsk, SibGPK, CJSC in Mezhdurechensk, etc.). Burning of finely dispersed waste coal in the form of briquettes receiving thermal and (or) electric energy is also one of the effective directions of its disposal.

Implementation of the specified method of waste recycling provides the most effective use of all mined coal for its intended purpose. Besides, the ash which is formed during burning is a good component for different construction materials. Application of such disposal technologies gives an opportunity to significantly reduce areas occupied with slurry fields, sludge ponds and tailing ponds, to reclamation disturbed lands and by that to improve ecological condition of the environment.

* Corresponding author: murkovi@,kuzstu.ru 
Thus, the transfer of waste coal - coal slimes - into technologically acceptable fuel will allow not only to improve an ecological situation in the region, but also to gain a significant economic effect.

\section{Experimental research}

For carrying out experimental investigation of kinetics of coal briquettes drying the briquette mixture was manually prepared in advance. As initial raw material the filter cake from Komsomolets and Kirov coal-preparation plants of SUEK-Kuzbass, CJSC was used.

Briquetting of the mixture consisting of filter cake from Kom somolets and Kirov coalpreparation plants was carried out on a small industrial auger and piston installation with the press BT.ShP 50.0 (figure 1) after mechanical activation on the industrial mechanoactivator.

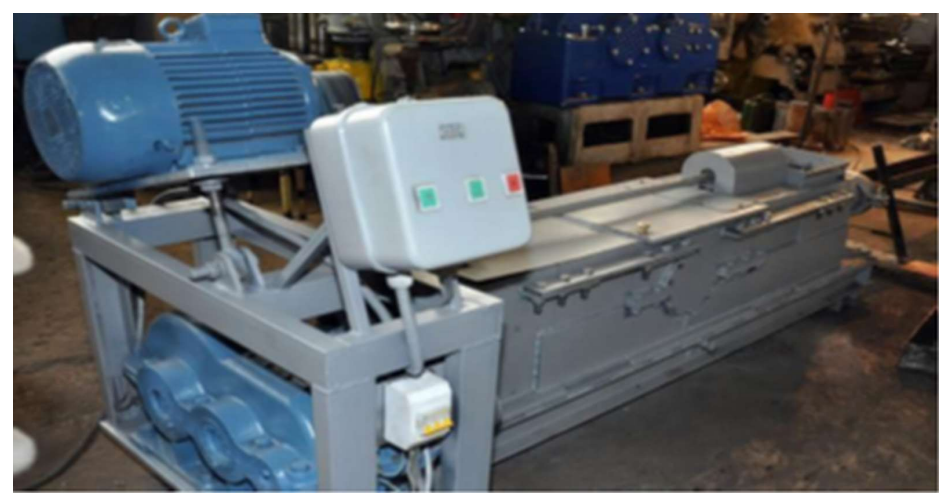

Fig. 1. Press BT.ShP 50.0.

The conducted investigations of briquetting of the mixture consisting of filter cake from the coal-preparation plants, previously dried at the atmospheric air to optimum humidity, on the high pressure auger and piston press, showed a possibility of preparation of briquettes of required quality. All pressed briquettes saved the form (Figure 2).

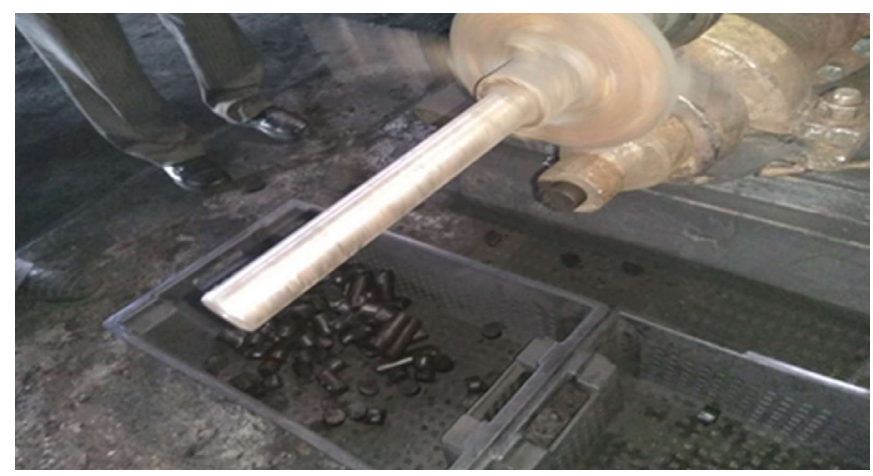

Fig. 2. Samples of briquettes.

After determination of the briquette mixture optimum humidity (humidity Wrt should be no more than $20.0 \%$ ) and the mode of its pressing, the researches of kinetics of the received briquettes drying were conducted. Coal briquettes were dried at the temperature of $110{ }^{\circ} \mathrm{C}$, $130^{\circ} \mathrm{C}$ and $160^{\circ} \mathrm{C}$ on the humidity analyzer MA-35 and additionally at the temperature from $160^{\circ} \mathrm{C}$ to $250^{\circ} \mathrm{C}$ in the muffle furnace. 
A damp briquette (directly after pressing) was subjected to drying. The change of the sample mass is presented on the diagram in relative units. The relative mass of the initial sample is taken as $100 \%$. The relative mass of the dried sample on the diagram corresponds to the value Mrel.

$$
M_{\text {rel }}=\frac{m}{M} \cdot 100 \%
$$

where $m$ - sample mass of a sample at the moment; $M$ - initial sample mass.

\section{Main results}

The results of kinetics of drying are presented graphically in Figures 3 and 4 .

As the diagram in figure 3 shows, after placing the sample in the heating medium there was a gradual reduction of the sample relative mass to the permanent value, i.e. to complete drying of the briquette. Increase in drying time of dry briquettes up to 2 hours at the specified temperatures did not lead to additional weight loss by means of devolatilization. As is seen in the same figure, the damp coal briquette was placed in the heating medium after it (medium) has achieved the temperature of $160^{\circ} \mathrm{C}$. During 20 minutes the coal briquette drying was taking place at the temperature maintained at the level of $160 \pm 5^{\circ} \mathrm{C}$. Further the medium was heated to the temperature $175 \pm 5^{\circ} \mathrm{C}$ and this value was maintained within 40 minutes. In 40 minutes after placing the briquette in the heating medium the sample mass reached $78 \%$ and did not change for more than 50 minutes. When the time of unchanged mass of the sample made 25 minutes, the temperature of the heating medium began to be increased. At the temperature increase to $220^{\circ} \mathrm{C}$ the tendency to the sample weight loss appeared.

Weight loss in the heating medium temperature range from $160^{\circ} \mathrm{C}$ to $220^{\circ} \mathrm{C}$ presented on figure 3 diagram is explained by the process of sample drying. It is supposed that there is no devolatilization at these temperature values what is shown by the horizontal section on the diagram of the sample mass change.

Figure 4 shows the dependence of warming up of the sample internal area on the heating medium temperature. Temperature of the sample internal area was measured by a chromelalumel thermocouple. Thickness of the thermocouple made $0.5 \mathrm{~mm}$. Thermocouple junction was placed in the zone close to the briquette axis at the distance from the ends exceeding the briquette diameter. The briquettes with diameter of $30 \mathrm{~mm}$ and length more than $60 \mathrm{~mm}$ were investigated. As is seen in the figure, at the heating medium temperature less than $180{ }^{\circ} \mathrm{C}$ the warm-up period, and consequently the drying time of the sample, is expected to be very long. Even in 30 minutes the temperature in the middle of the sample did not reach $90{ }^{\circ} \mathrm{C}$. In the course of drying there is the diffusion of water to the surface. Only at increase of the heating medium temperature up to $200-220^{\circ} \mathrm{C}$ the temperature in the middle of the sample increased to $80-90{ }^{\circ} \mathrm{C}$. The growth of temperature in the center to the values exceeding $100{ }^{\circ} \mathrm{C}$ is observed only in an hour after placing the sample in the heating medium. As is seen in the figure 3 , this time practically matches the time of sample drying.

Thus, the expected drying time of briquettes makes about 1 hour. Depending on the accepted drying method (to $10 \%$ or $15 \%$ ) the required time can be defined when carrying out commissioning, but, as the diagram in figure 3 shows, it cannot be less than 45 minutes. When performing calculations for the drying installation, it is reasonable to accept that the required drying time makes 60 minutes. 


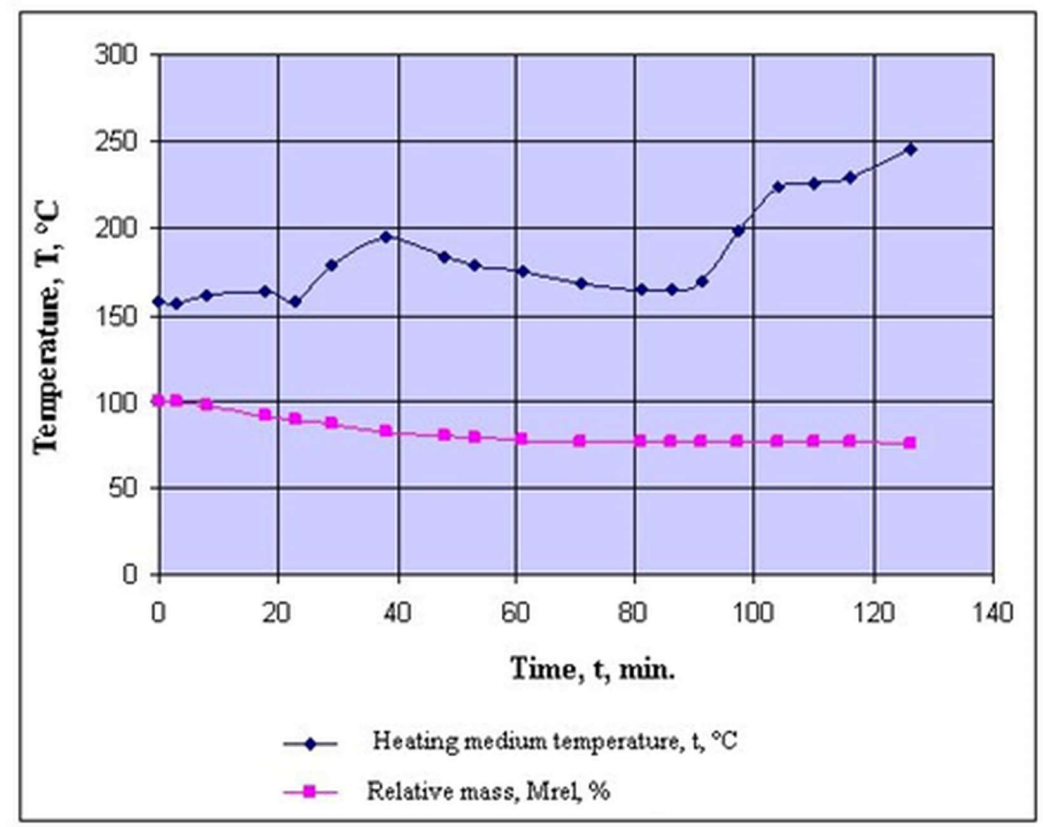

Fig. 3. Dependence of drying processes on the heating medium temperature.

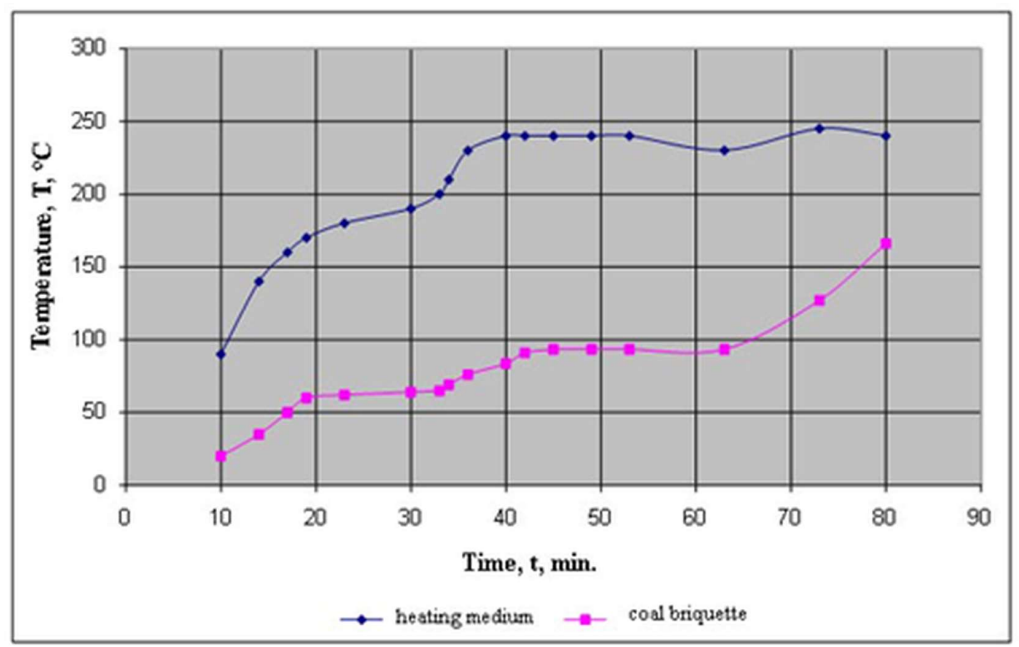

Fig. 4. Dependence of the briquette warming up on the heating medium temperature.

On the contrary, the weight loss tendency at temperature increase higher than $220{ }^{\circ} \mathrm{C}$ testifies to the beginning of devolatilization process.

Thus, to provide fire and explosion safety of the drying process due to prevention of devolatilization, it is recommended to perform the process at the heating medium temperature not exceeding $200{ }^{\circ} \mathrm{C}$.

\section{Conclusions}

Experimental briquetting of the mixture of filter cake received from Komsomolets and Kirov coal-preparation plants was conducted. As a result it was found that to receive qualitative 
briquettes it is necessary to maintain optimum humidity of initial mixture of around $20 \%$ at the filter cake initial humidity of $35 \%$. To ensure humidity of ready briquettes of around 10 $15 \%$ their thermal drying is required. For this purpose the fire and explosion safe technology for thermal drying of coal briquettes prepared on the basis of finely dispersed waste coal with use of combustion gases was developed and proved.

\section{References}

1. V. Murko, V. Karpenok, Y. Senchurova, O. Tailakov, A. Bogomolov, V. Khyamyalyainen, MATEC Web of Conferences, 72, 01074 (2016)

2. A. Papin, A. Ignatova, A. Nevedrov, T. Cherkasova, Eur. Phys. Journal of Mining Science, 51 (5), 895 (2015)

3. L. Antipenko, N. Khashina, International Coal Preparation Congress, 547 (2010)

4. M. Shkoller, S. Kazimirov, M. Temlyantsev, A. Basegskiy, Coke and Chemistry, 58(12), 482 (2015)

5. S. Kuznetsov, M. Shkoller, E. Protopopov, M. Temlyantsev, S. Feiler, Steel in Translation, 47(4), 229 (2017) 